\title{
ABSTRACTS
}

\section{Affirmative Action in South Africa: (M)Any Lessons for Europe?}

\author{
By Ockert Dupper, Stellenbosch / München
}

This is a paper about affirmative action in South Africa, and the possible lessons that Europe can learn from the South African experience. Since 1994, affirmative action has occupied a prominent place on the South African legal landscape. Despite explicit constitutional and legislative endorsement, affirmative action in South Africa has nevertheless remained deeply controversial. Many legal challenges have been launched against affirmative action programmes over the past number of years, meaning that South African courts, like courts elsewhere, have had to confront the now familiar tension between the equal treatment principle and substantive conceptions of equality. In the paper, the author argues that the South African experience with affirmative action measures is unique in a number of respects, of which two stand out. The first relates to the constitutional and legislative framework. Unlike the situation in many other countries, the South African Constitution makes explicit reference to affirmative action. In addition, it refers to affirmative action in terms that leave no doubt that such measures are not to be viewed not as a deviation from an equal treatment principle, but as a means to ensure the achievement of substantive equality. Secondly, in giving meaning to the notion of substantive equality, the legislature and the judiciary in South Africa have challenged many conventional wisdoms in the area of affirmative action, one of the most significant being the "traditional" or "conventional" understanding of the notion of merit.

\section{Taiwan as a Permanent Observer at the World Health Organization (WHO)?}

\author{
By Rainer Lagoni, Hamburg
}

Taiwan is not a member of the World Health Organization and the status of a permanent observer is not mentioned in the Constitution of the World Health Organization. However, the Rules of Procedure of the World Health Assembly contain some reference to observers, but they apply to States with a view to become a member of the WHO. Therefore they are not appropriate for Taiwan. For the same reason a practice has evolved in regard to the current six permanent observers, none of which is a State as well, that the Executive Board 
authorizes the Director-General to invite the interested party as a permanent observer on its request. Similarly, a pragmatic approach should be taken with regard to the issue, whether or not a Taiwanese "health entity" should be granted a permanent observer status at the WHO. The objective of the World Health Organization, which is the attainment by all peoples of the highest possible level of health, requires that the 23 million people who live on the island of Taiwan shall be taken into account. They cannot by fact be represented effectively by the People's Republic of China in health matters. Being a permanent observer is independent of the status of Taiwan and therefore does not touch upon the One China Policy. Neither does it affect the resolutions of the United Nations and the World Health Organization relating to the representation of China at these international organizations. For these reasons, an inclusion of Taiwan in the system of the World Health Organization as a "health entity" with the status of a permanent observer at the World Health Assembly is vital for the protection of the health of the population of Taiwan and of other peoples as well.

\title{
International Water Law in the La Plata Basin: Regional Application of Principles and Procedural Rules of General International Water Law
}

\author{
By Mariana Suzuki Sell, Rio de Janeiro
}

The importance of the La Plata Basin emanates from the central political and economic position it occupies in South America, as well as from its ecosystems wealth. As the economies of its riparian States developed around the Basin, the use of its waters brought about regional conflicts, on one hand, and new forms of cooperation, on the other. The International Water Law began to develop in the region especially from the late 60s, when the Intergovernmental Coordinating Committee (CIC) was established. The La Plata Basin Treaty (1969) and the Asunción Declaration (1971) recognized the international principles of cooperation, equitable and reasonable utilization, no significant harm, and sustainable development. However, along the years the Basin States implemented projects in disregard for the co-riparian interests. Recently, with the CIC's revitalization, the basin unity principle is emerging again. For instance, the Framework Agreement for the Sustainable Water Resources Management in the La Plata Basin and the Project for the Environmental Protection and Sustainable Development of the Guarani Aquifer System reflect a tendency towards integrated management, public participation, and sustainable use. Depending on the results of the ongoing projects, the Basin could become a model to be applied to other transboundary basins. 
The right to a natural judge: Interplay of constitutional and international human rights law in Latin America

\section{By Jeanine Bucherer, Düsseldorf}

The right to a natural judge is clearly a core element of the right to a fair trial in constitutional law. Generally, it demands that the competent court as well as the competent judge be defined prior to a given trial and that the so defined judge actually rules the case. Thus, the right to a natural judge is closely linked with the national order of competencies.

What about international law? In Latin America, the Inter-American Court of Human Rights introduced the concept of "natural judge" to restrict military tribunals' competencies as regards trials against civilians and trials against members of the armed forces accused of human rights violations.

The contribution focuses on the interplay of constitutional and international human rights law. More specifically, it describes developments in Peruvian constitutional law related to the Inter-American court's jurisprudence on military tribunals and the natural judge. 